\title{
Corrosion Evaluation of SAW Welded API 5L X-80 Joints in $\mathrm{H}_{2} \mathrm{~S}-$-Containing Solution
}

\author{
Adriana Forero Ballesteros ${ }^{a}$, José Antônio Ponciano Gomes ${ }^{b}$, I. S. Bott ${ }^{a *}$ \\ ${ }^{a}$ Departamento de Engenharia Química e de Materiais, Pontíficia Universidade Católica do Rio de \\ Janeiro, Rua Marquês de São Vicente, 225, CP 38097, CEP 22453-900, Gávea, \\ Rio de Janeiro, RJ, Brasil \\ ${ }^{b}$ Departamento de Engenharia Metalúrgica e de Materiais, Universidade Federal do Rio de \\ Janeiro - UFRJ, Ilha do Fundão, Centro de Tecnologia, Bloco F, Rio de Janeiro, RJ, Brasil
}

Received: December 15, 2014; Revised: April 1, 2015

\begin{abstract}
The $\mathrm{H}_{2} \mathrm{~S}$ corrosion resistance of API 5L X80 steel and its welded joint (WJ) were evaluated using the weight loss method in a $5 \% \mathrm{wt}$ brine solution and different corrosive environments based on a sodium thiosulphate solution $\left(10^{-3}\right.$ and $\left.10^{-2} \mathrm{~mol} / \mathrm{l}\right)$. The weight loss method, scanning electron microscopy (SEM) and X-ray diffraction analysis (XRD) were applied to measure the effects of different $\mathrm{H}_{2} \mathrm{~S}$ concentrations and $\mathrm{pH}$ ( 3 and 5) on the corrosion process and formation of corrosion product films. The results showed that the obtained corrosion rate and corrosion product films for both API 5L X80 steel and its submerged arc welding (SAW) WJ depend on the $\mathrm{pH}, \mathrm{H}_{2} \mathrm{~S}$ concentration and metal surface microstructural characteristics. The corrosion product film consists of two layers with different morphologies. The heat affected zone (HAZ) shows severe localized corrosion attack relative to the base metal $(\mathrm{BM})$ and weld metal (WM), which is attributed to the microstructural characteristics of this region.
\end{abstract}

Keywords: corrosion, $H_{2} S$, steel, welded joint, localized attack

\section{Introduction}

The corrosion evaluation of metallic materials in oil and gas refinery environments is particularly important because corrosion can cause economic and human losses. It is well known that $\mathrm{H}_{2} \mathrm{~S}$ originating from different processes in the oil and gas industry can accelerate the anodic and cathodic reactions of the corrosion process: iron dissolution and hydrogen evolution reaction, respectively ${ }^{1-10}$. Studies focusing on improving the resistance of pipeline steels to $\mathrm{H}_{2} \mathrm{~S}$ corrosion to avoid failures during oil and gas transport have been reported ${ }^{9-14}$. In Brazil, the manufacture and use of high-strength low-alloy steel pipelines have been implemented in recent decades; these pipelines are nationally produced using thermomechanical controlled processing (TMCP) without accelerated cooling and fabricated using the UOE process (pressing a U-shaped pipe between two semi-circular dies to form an O-shaped pipe, then welding the pipe closed and circumferentially expanding it to obtain a highly circular shape) for the conduction of liquid and gaseous hydrocarbons. These materials have been developed with specific chemical and mechanical properties, such as mechanical strength, weldability, ductility, resistance to corrosion and hydrogen embrittlement, by adding microalloying elements, such as niobium, vanadium and titanium ${ }^{15-16}$.

$\mathrm{H}_{2} \mathrm{~S}$ is extremely soluble in water. Gaseous $\mathrm{H}_{2} \mathrm{~S}$ dissolved in an aqueous phase behaves as a weak acid and often causes pitting corrosion of the pipeline. The corrosion process is generally accompanied by the formation of several iron sulphide phases, as the weak acid formed attacks the iron

*e-mail: bott@.puc-rio.br and forms insoluble iron sulphide. The reactions that occur according to the mechanism proposed by Cheng et al..$^{5}$ are

$\mathrm{Fe} \rightarrow \mathrm{Fe}^{+2}+2 \mathrm{e}^{-}$

$2 \mathrm{H}^{+} 2 \mathrm{e}^{-} \rightarrow \mathrm{H}^{\circ}$

$\mathrm{Fe}+\mathrm{H}_{2} \mathrm{~S}+\mathrm{H}_{2} \mathrm{O} \leftrightarrow\left(\mathrm{FeSH}^{-}\right)$ads $+\mathrm{H}_{3} \mathrm{O}^{+}$

$\left(\mathrm{FeSH}^{-}\right)$ads $\leftrightarrow(\mathrm{FeSH}) \mathrm{ads}+\mathrm{e}^{-}$

$(\mathrm{FeSH}) \leftrightarrow \mathrm{FeSH}^{+}+\mathrm{e}^{-}$

$\mathrm{FeSH}^{+}+\mathrm{H}_{3} \mathrm{O}^{+} \leftrightarrow \mathrm{Fe}^{+2}+\mathrm{H}_{2} \mathrm{~S}+\mathrm{H}_{2} \mathrm{O}$

The $\mathrm{H}_{2} \mathrm{~S}$ corrosion resistance properties of steels depend on the steel cleanliness and microstructure ${ }^{11-21}$. The welding procedures adopted during tube production in pipeline construction can modify the microstructural and consequently the mechanical properties of the heat affected zone (HAZ). As a result, there is an increasing incidence of different types of corrosion in these regions $\mathrm{s}^{15,19-24}$.

In the present work, weight loss tests, scanning electron microscopy (SEM) and X-ray diffraction analysis (XRD) were applied to measure the effects of different $\mathrm{H}_{2} \mathrm{~S}$ concentrations and $\mathrm{pH}(3$ and 5$)$ on the corrosion process and corrosion product films that were formed on API 5L X80 steel (base metal (BM) and its welded joint (WJ)). The results show that the obtained corrosion rates and characteristics of the 
corrosion product films for all regions of the WJ (BM, WM and HAZ) and the BM alone depend on the solution $\mathrm{pH}$, $\mathrm{H}_{2} \mathrm{~S}$ concentration and steel microstructure; for example, a severe attack in the HAZ was evidenced, which indicates the effect of the microstructure on the corrosion attack mechanism.

\section{Experimental Procedures}

\subsection{Materials}

Samples were obtained from two different regions: the longitudinal joint, which was obtained using submerged arc welding (SAW) and therefore contained all three regions (BM, WM and HAZ), as shown in Figure 1, and the fully $\mathrm{BM}$. The average values of the chemical composition sampled from two different points (Figure 2) of the BM and WJ were obtained using the optical emission spectroscopy technique according to ASTM E 415-2008 ${ }^{25}$, as shown in Table 1.

The microstructural characterization of the $\mathrm{WJ}$ is presented in Figure 3. The BM consists of a ferritic matrix with martensite and austenite microconstituent (MA); the WM microstructure is mainly acicular ferrite and grain boundary ferrite. The HAZ usually exhibits a ferrite bainitic microstructure with decomposed MA microconstituent regardless of region; in some regions of the fine-grain HAZ, polygonal and almost polygonal ferrites are observed.

\subsection{Weight loss tests}

The effects of $\mathrm{pH}, \mathrm{H}_{2} \mathrm{~S}$ concentration and microstructural characteristics on the corrosion rate and corrosion film morphology were studied for the BM and a longitudinal SAW WJ of API 5L X80 steel. Weight loss tests were conducted in a $5 \% \mathrm{wt} \mathrm{NaCl}$ brine and different corrosive environments based on a sodium thiosulphate solution, as listed in Table 2. $\mathrm{H}_{2} \mathrm{~S}$ was indirectly generated from the reaction of the solution with the metal surface at atmospheric pressure and room temperature, without removing oxygen from the system. The specimens with dimensions of $40 \times 15 \times 5 \mathrm{~mm}$ were produced in triplicate to determine the reproducibility of the test. The samples were washed, polished with sandpaper (220-600 mesh) and weighed before the test began. At least

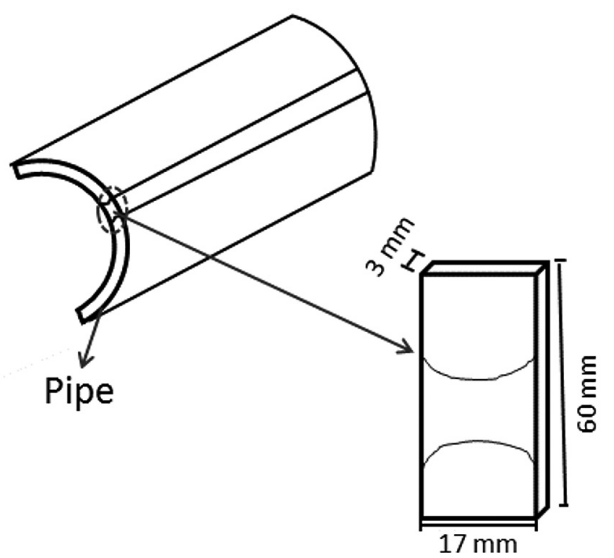

Figure 1. Specimen dimensions in $\mathrm{mm}$. three samples from each region (BM and WJ) were submitted to identical conditions for 30 days. After exposure to the testing environment, the samples were removed from the solution, and the corrosion products were removed from the specimen surfaces by scrubbing with a non-metallic bristle brush. After the removal, the specimens were cleaned, dried and re-weighed according to the ASTM G1-03(2011) standard $^{26}$. The corrosion rate was then calculated as the

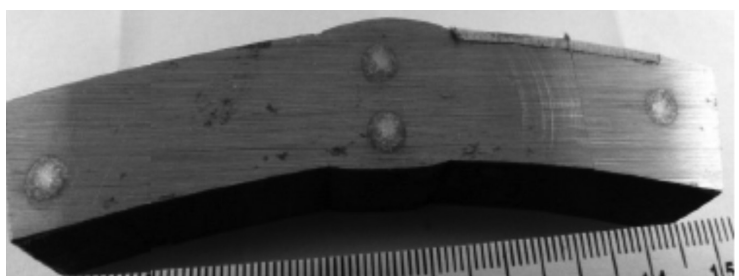

Figure 2. Sampling regions for chemical composition using optical emission spectroscopy.

Table 1. Chemical composition of the base metal and weld metal in $w t \%$.

\begin{tabular}{cccc}
\hline Element & $\begin{array}{c}\text { Base Metal } \\
\text { (wt \%) }\end{array}$ & $\begin{array}{c}\text { Weld Metal } \\
\text { (wt \%) }\end{array}$ & $\begin{array}{c}\text { API 5L } \\
\text { Standard } \\
\text { Maximum } \\
\text { (wt \%) }\end{array}$ \\
\hline (C) & 0.058 & 0.056 & 0.22 \\
(Si) & 0.203 & 0.273 & - \\
$(\mathrm{Mn})$ & 1.71 & 1.59 & 1.85 \\
$(\mathrm{P})$ & 0.023 & 0.027 & 0.025 \\
$(\mathrm{~S})$ & 0.0031 & 0.0062 & 0.015 \\
$(\mathrm{Cr})$ & 0.131 & 0.100 & - \\
$(\mathrm{Ni})$ & 0.020 & 0.023 & - \\
$(\mathrm{Mo})$ & 0.192 & 0.178 & - \\
$(\mathrm{Al})$ & 0.044 & 0.021 & - \\
$(\mathrm{Cu})$ & 0.011 & 0.050 & - \\
$(\mathrm{Co})$ & $<0.0015$ & $<0.0015$ & - \\
$(\mathrm{Ti})$ & 0.015 & 0.014 & $\mathrm{c}, \mathrm{d}$ \\
$(\mathrm{Nb})$ & 0.064 & 0.037 & $\mathrm{c}, \mathrm{d}$ \\
$(\mathrm{V})$ & 0.023 & 0.017 & $\mathrm{c}, \mathrm{d}$ \\
$(\mathrm{B})$ & 0.0007 & 0.0027 & - \\
$(\mathrm{Ca})$ & 0.0032 & 0.0016 & - \\
$(\mathrm{Fe})$ & Balance & Balance & \\
\hline
\end{tabular}

c: Niobium, vanadium, titanium, or combinations thereof may be used at the discretion of the manufacturer. $\mathrm{d}$ : Sum of the niobium, vanadium, and titanium contents do not exceed $0,15 \%$ (API 5L, 2007).

Table 2. Chemical composition of the solutions used in the weight loss tests.

\begin{tabular}{cccc}
\hline Solution & $\begin{array}{c}\text { Sodium } \\
\text { Thiosulphate } \\
\left(\mathbf{N a}_{2} \mathbf{S}_{2} \mathbf{O}_{3}\right)\end{array}$ & $\begin{array}{c}\text { Sodium Chloride } \\
(\mathbf{N a C l})\end{array}$ & $\mathbf{p H}$ \\
\hline Brine & 0 & & 5.0 \\
Solution 1 & $10^{-3} \mathrm{~mol} / 1$ & & \\
Solution 2 & $10^{-2} \mathrm{~mol} / 1$ & $5 \% \mathrm{wt}$ & \\
Brine & 0 & & 3.0 \\
Solution 1 & $10^{-3} \mathrm{~mol} / 1$ & & \\
Solution 2 & $10^{-2} \mathrm{~mol} / 1$ & & \\
\hline
\end{tabular}




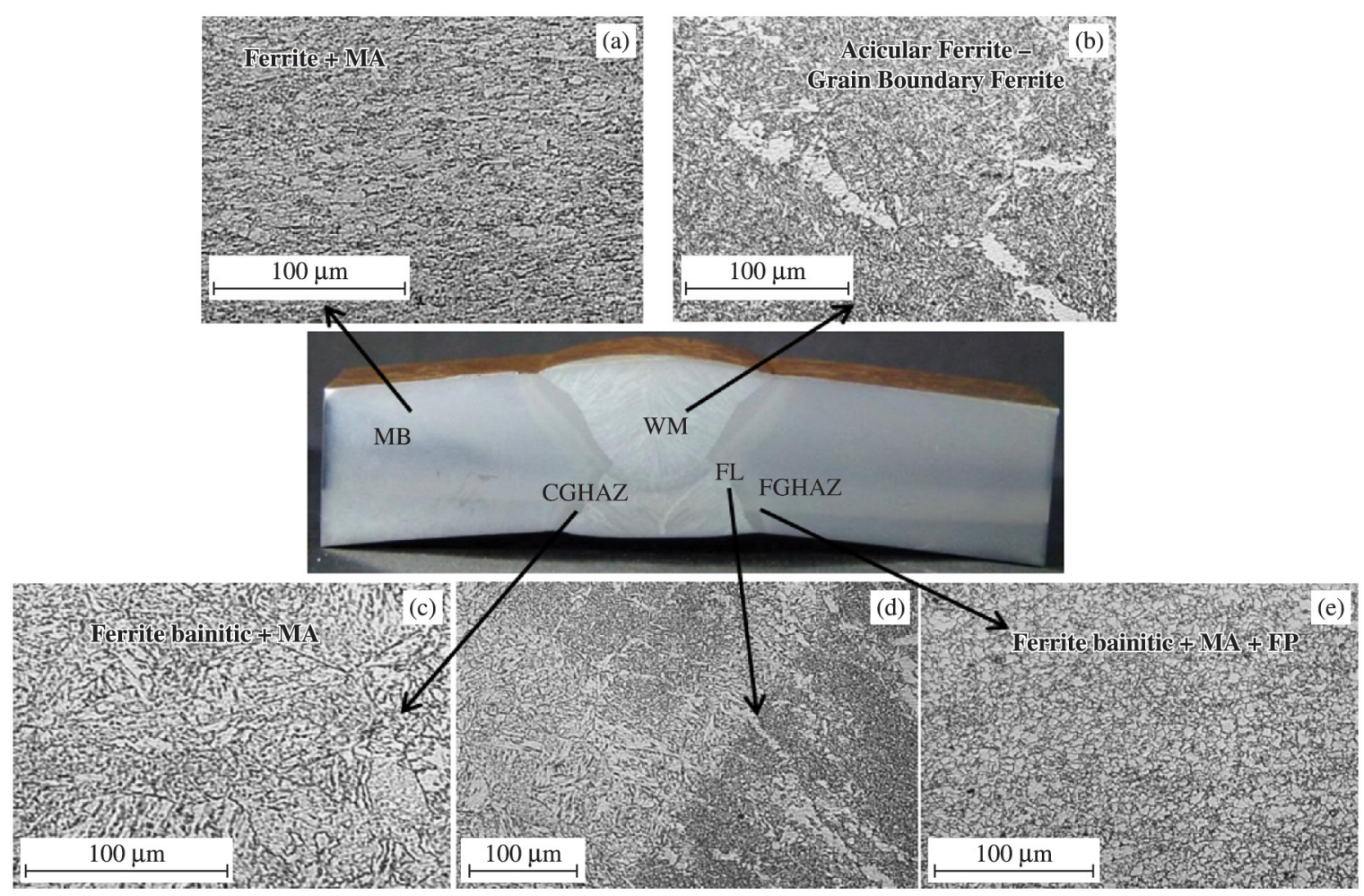

Figure 3. Microstructural characterization of the welded joint. a) Base metal (BM). b) Weld metal (WM). c) Coarse grain heat affected zone (CGHAZ). d) Fusion line (FL). e) Fine grain heat affected zone (FGHAZ).

average of the results obtained from three different samples using the following equation:

Corrosion Rate $(\mathrm{mpy})=\left(\frac{\mathrm{K} * \mathrm{~W}}{\mathrm{~A} * \mathrm{~T} * \mathrm{D}}\right)$

where $\mathrm{K}=$ a constant $=3.45 \times 10^{6}, \mathrm{~W}=$ mass loss in $\mathrm{g}, \mathrm{A}=$ area in $\mathrm{cm}^{2}, \mathrm{~T}=$ time in hours and $\mathrm{D}=$ density in $\mathrm{g} / \mathrm{cm}^{3}(7.85)$.

Visual, optical microscopy (OM) and SEM analyses of the samples surfaces were performed to determine the type and morphology of the corrosion film.

\section{Results and Discussion}

The average corrosion rates obtained in the loss weight tests of both materials (BM and $\mathrm{WJ}$ ) in different $\mathrm{H}_{2} \mathrm{~S}$-containing solutions are recorded in Table 3 and Figure 4 . The corrosion rates increase with decreasing $\mathrm{pH}$ of the solution, and this effect is more significant for solution 2. In aqueous environments, hydrogen sulphide dissociates and produces different chemical species with different concentrations depending on the $\mathrm{pH}$, temperature and $\mathrm{H}_{2} \mathrm{~S}$ concentration. For each $\mathrm{pH}$ value, the predominant chemical species determines the oxidation and reduction reactions and characterizes the corrosive process ${ }^{1-3}$. According to $\mathrm{Kane}^{27}$, for most steels in $\mathrm{H}_{2} \mathrm{~S}$-containing environments, the corrosion rates tend to increase with decreasing $\mathrm{pH}$ of the aqueous solution. The stable form of $\mathrm{H}_{2} \mathrm{~S}$ depends on the solution acidity $(\mathrm{pH}) . \mathrm{H}_{2} \mathrm{~S}$ is only stable as a dissolved species in aqueous solutions at low $\mathrm{pH}$ levels $(\mathrm{pH} \leq 6)$; at higher $\mathrm{pH}$ levels (7-11), the predominant form is $\mathrm{HS}^{-}$, and for alkaline $\mathrm{pH}$ values, the stable form is $\mathrm{S}^{2-}$.
Table 3. Average corrosion rate obtained from the weight loss tests in different environments

\begin{tabular}{lccc}
\hline \multicolumn{1}{c}{ Solution } & Material & $\begin{array}{c}\text { Rcorr } \\
(\mathbf{m m} / \mathbf{y})\end{array}$ & $\begin{array}{c}\text { Rcorr } \\
(\mathbf{m p y})\end{array}$ \\
\hline Brine $\mathrm{pH}=5.0$ & $\mathrm{BM}$ & 0.12 & 4.94 \\
& $\mathrm{WJ}$ & 0.146 & 5.76 \\
Brine $\mathrm{pH}=3.0$ & $\mathrm{BM}$ & 0.23 & 8.99 \\
& $\mathrm{WJ}$ & 0.25 & 9.73 \\
$\mathrm{Sol} \mathrm{1.} 10^{-3} \mathrm{~mol} / \mathrm{L} \mathrm{Na}_{2} \mathrm{~S}_{2} \mathrm{O}_{3}$, & $\mathrm{BM}$ & 0.086 & 3.39 \\
$\mathrm{pH}=5.0$ & $\mathrm{WJ}$ & 0.093 & 3.69 \\
$\mathrm{Sol} 1.10^{-3} \mathrm{~mol} / \mathrm{L} \mathrm{Na}_{2} \mathrm{~S}_{2} \mathrm{O}_{3}$, & $\mathrm{BM}$ & 0.112 & 4.41 \\
$\mathrm{pH}=3.0$ & $\mathrm{WJ}$ & 0.109 & 4.33 \\
$\mathrm{Sol} \mathrm{2.} 10^{-2} \mathrm{~mol} / \mathrm{L} \mathrm{Na}_{2} \mathrm{~S}_{2} \mathrm{O}_{3}$, & $\mathrm{BM}$ & 0.143 & 5.63 \\
$\mathrm{pH}=5.0$ & $\mathrm{WJ}$ & 0.148 & 5.82 \\
$\mathrm{Sol} \mathrm{2.} 10^{-2} \mathrm{~mol} / \mathrm{L} \mathrm{Na}_{2} \mathrm{~S}_{2} \mathrm{O}_{3}$, & $\mathrm{BM}$ & 0.394 & 15.04 \\
$\mathrm{pH}=3.0$ & & & \\
\hline
\end{tabular}

According to Shoesmith ${ }^{3}$ and Ma et al. ${ }^{5}$, in alkaline solutions, the corrosion rate decreased because of the formation of FeS, which is favoured by the reduced solubility of the solid sulphur and the less prevalent hydrogen reduction reaction. For $\mathrm{pH}$ higher than 7 , a sulphide layer capable of promoting surface passivation is formed. For $\mathrm{pH}$ between 4 and 7, the sulphide layer breaks down and allows the iron dissolution to proceed, which increases the formation of precipitates from the same sulphide on the initial layer. Below $\mathrm{pH} 4$, the solubility of the sulphide is increased by reducing the amount of precipitates on the surface ${ }^{3,5}$. At lower $\mathrm{pH}$ values (less than 3 ), the amount of precipitate 
on the steel surface is small, and some solid product of the reaction may appear.

Figure 5 shows the surface appearance of some of the specimens that were tested for weight loss before the removal of corrosion products. The growth of a thicker, more discontinuous layer was observed for solutions with $\mathrm{pH}=5.0$ relative to the layers formed for solutions with $\mathrm{pH}=3.0$ for all studied conditions. After the corrosion products were removed from the metal surface, preferential attack was observed in the form of pitting. In solutions with $\mathrm{pH}=5.0$, in most tests, the BM and WM show uniform

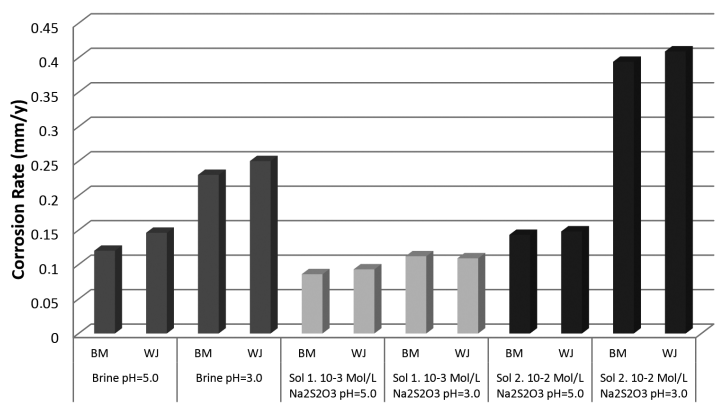

Figure 4. Average corrosion rates obtained by weight loss tests in different solutions.

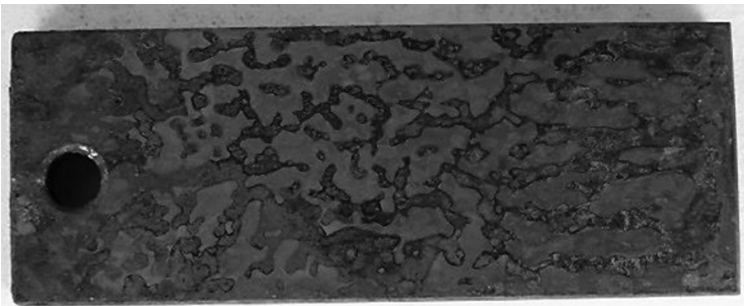

(a)

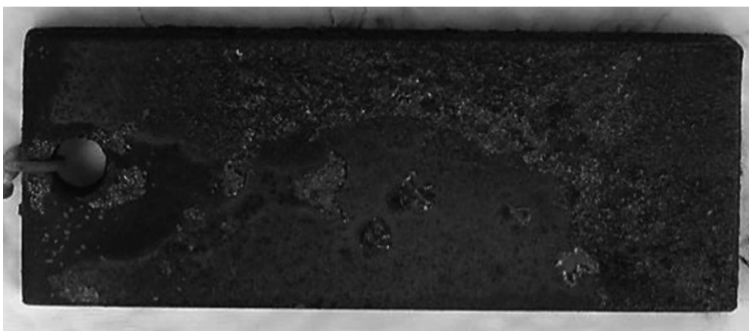

(c)

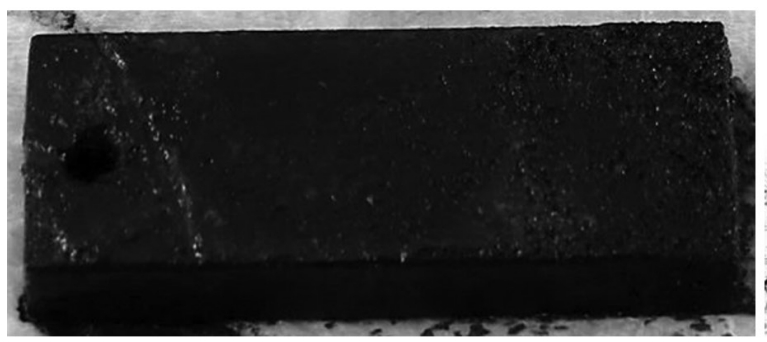

(e) corrosion, and localized attack was observed for the HAZ, as shown in Figure 6a. For solutions with $\mathrm{pH}=3.0$, localized attack was observed for all regions of the $\mathrm{WJ}$, and it was more severe for the HAZ in solution 2 than in solution 1 , as shown in Figures $6 \mathrm{~b}$ and $6 \mathrm{c}$.

In general, iron corrosion in $\mathrm{H}_{2} \mathrm{~S}$-containing solutions leads to the formation of a FexSy film, where the type of sulphide depends on the $\mathrm{H}_{2} \mathrm{~S}$ concentration in the solution.

Considering the $\mathrm{H}_{2} \mathrm{~S}$ concentration of the solutions in this work, the corrosion rate was lower for the brine with solution $1\left(10^{-3} \mathrm{~mol} / \mathrm{L} \mathrm{Na}_{2} \mathrm{~S}_{2} \mathrm{O}_{3}\right)$ and higher for solution $2\left(10^{-2} \mathrm{~mol} / \mathrm{L} \mathrm{Na}_{2} \mathrm{~S}_{2} \mathrm{O}_{3}\right)$. This effect is thought to be caused by the formation of a partially protective film on the samples in solutions with low $\mathrm{H}_{2} \mathrm{~S}$ concentration.

In general, higher $\mathrm{H}_{2} \mathrm{~S}$ concentrations have been found to correspond to higher steel corrosion rates ${ }^{1-9,15,24,28-33}$ because both anodic dissolution and hydrogen evolution processes are accelerated. However, under certain special operating conditions with low $\mathrm{H}_{2} \mathrm{~S}$ concentrations $(<0.04 \mathrm{mmol} / \mathrm{l},<15 \mathrm{ppm}$ or $<0.05 \mathrm{psi}$ ), $\mathrm{pH}$ values of 3-5 and immersion times exceeding two hours, the corrosion process can be inhibited, which significantly decreases the corrosion rate ${ }^{1-9}$, as shown in the results obtained for solution 1 in this study.

The $\mathrm{H}_{2} \mathrm{~S}$ corrosion process tends to form iron sulphide $\left(\mathrm{Fe}_{\mathrm{x}} \mathrm{S}_{\mathrm{y}}\right)$ films. Although this film can facilitate hydrogen

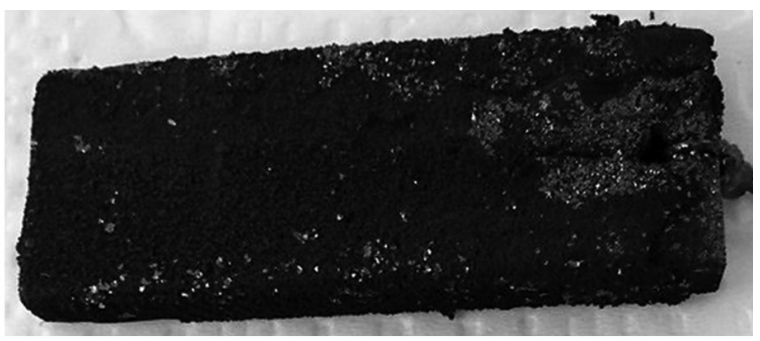

(b)

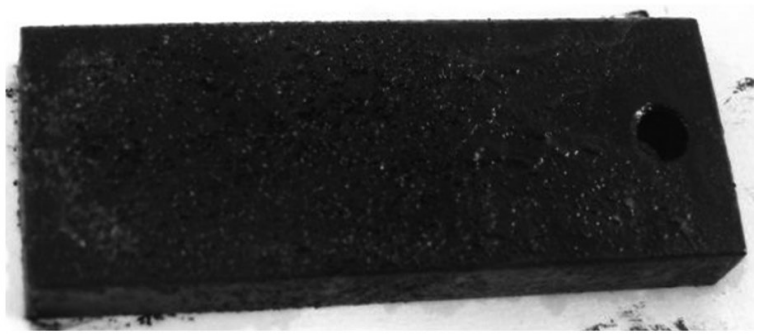

(d)

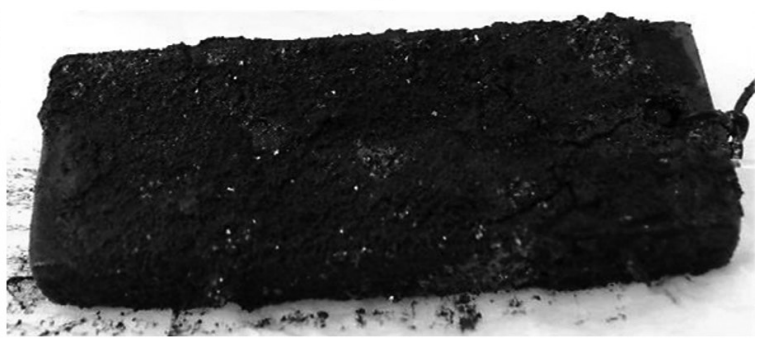

(f)

Figure 5. a) Welded joint in brine, $\mathrm{pH}=5.0$; b) base metal in brine, $\mathrm{pH}=3.0$; c) welded joint in solution 1, $\mathrm{pH}=5.0$; d) welded joint in solution $1, \mathrm{pH}=3.0$; e) welded joint in solution $2, \mathrm{pH}=5.0$; f) welded joint in solution 2, $\mathrm{pH}=3.0$. 


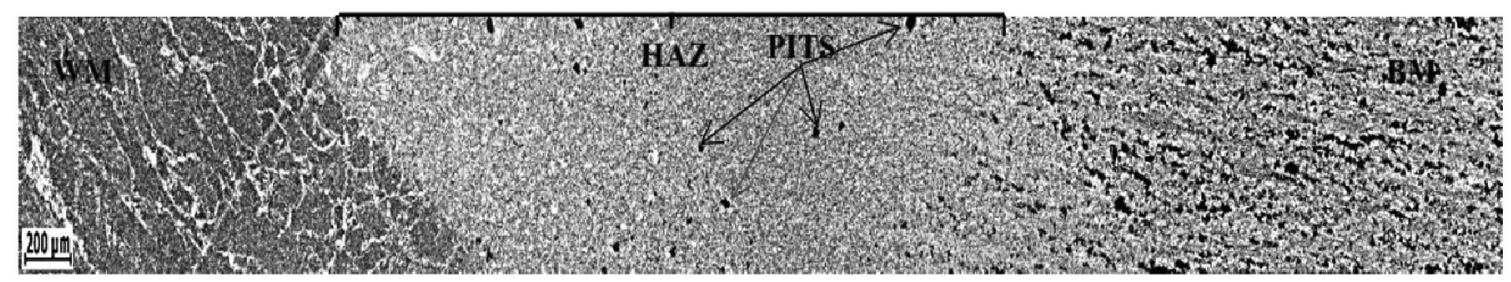

(a)

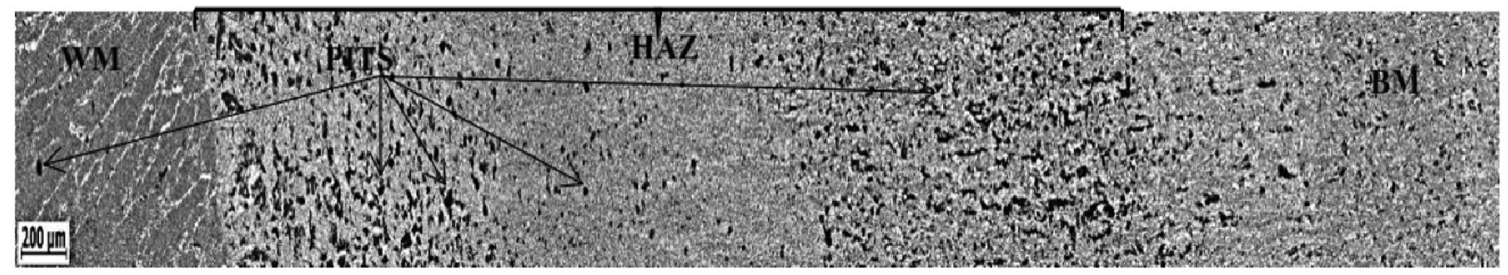

(b)

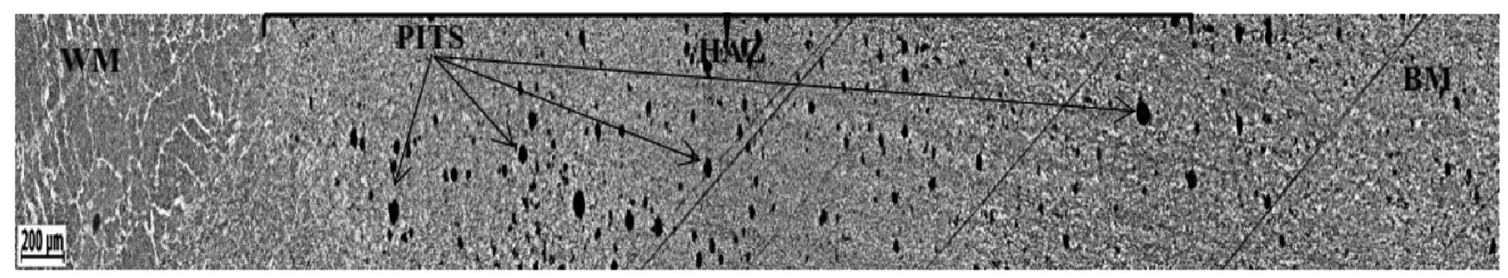

(c)

Figure 6. OM images of the surface appearance of the specimens after the removal of corrosion products in different environments. (a) WJ in brine, $\mathrm{pH}=5.0$. b) WJ in solution 1, $\mathrm{pH}=3.0$. c) WJ in solution 2, $\mathrm{pH}=3.0$.

permeation, it can also act as a physical barrier between the metal and the medium, reducing the corrosion rate ${ }^{23}$. Because these films can vary widely in composition and stoichiometry, the protective effect depends on the conditions of the environment in which they are formed $(\mathrm{pH}$, sulphide concentration, presence of chlorides, formation time, liquid or gas phase and microstructure of the substrate) $)^{2,6,8,9,13,19,21,23}$. In the present case, an increase in the corrosion rate was observed for solution 2, which indicates that the formed film was not protective under these conditions. For solution 1 , a decrease in the corrosion rate was observed for the two studied $\mathrm{pH}$ values, which indicates the formation of a film that inhibits the corrosion process of the metal substrate under these conditions. These results suggest that the $\mathrm{H}_{2} \mathrm{~S}$ concentration has a stronger effect than $\mathrm{pH}$ on the protective level of the film that forms in different test environments.

It has been found that for unsaturated $\mathrm{H}_{2} \mathrm{~S}$ solutions, a type of sulphur called mackinawite $\left(\mathrm{Fe}_{1}+{ }_{\mathrm{X}} \mathrm{S}\right)$ is initially precipitated and later becomes troilite (hexagonal FeS). Next, a cubic ferrous sulphide is formed. These phases continually precipitate until reaching a $\mathrm{pH}$ value of 4 . Below this $\mathrm{pH}$, the solubility of these sulphides is sufficiently high for the corrosion rates to also be high. Above $\mathrm{pH}=7$, a passivating film of mackinawite is developed ${ }^{1-3}$. At $\mathrm{pH}$ values of 3-5, an inhibitive effect of $\mathrm{H}_{2} \mathrm{~S}$ is observed, as a protective ferrous sulphide film (FeS) forms on the electrode surface ${ }^{3,9}$. Because the corrosion rate is significantly affected by the corrosion product film, the corrosion products were observed visually
(Figure 5) and using SEM (Figures 7-8). The structure and composition of the films were determined using EDS and XRD (Figures 7-10).

The layer exhibits a discontinuous and porous morphology and was mainly formed from oxides, sulphides and chlorides, as shown in the EDS spectra recorded for different areas of the layers (Figures 7-8).

For the specimen tested in solution 2 with $\mathrm{pH}=3.0$, visual inspection (Figure 5f) suggests the presence of two layers, as shown in Figure 7: an outer layer with crystals formed on top of a porous and irregular black layer. Two different morphologies can be observed. The first black layer grows adjacent to the metal surface, may be mackinawite, and shows some degree of porosity. The second layer consists of crystal clusters with a columnar geometry of possibly a more stable iron sulphide, as suggested by the EDS spectrum.

Figure $7 \mathrm{~b}$ shows the EDS spectra from different areas of the layer formed on the MB-HAZ interface. The first layer shows the presence of $\mathrm{Fe}, \mathrm{Cl}, \mathrm{Ni}, \mathrm{Na}, \mathrm{Mn}$ and $\mathrm{O}$, whereas the second layer (columnar crystal) is mainly composed of $\mathrm{S}, \mathrm{Fe}$, and $\mathrm{Na}$. The spectra obtained from the layers that were apparently formed first indicate the presence of oxygen in this layer; thus, it can be said that an oxide layer was initially formed and became a type of meta-stable sulphide (mackinawite). Above this layer formed crystals with columnar geometry, which appear to be a type of sulphide enriched in sulphur. This assessment is supported by the XRD spectrum shown in Figure 9. 


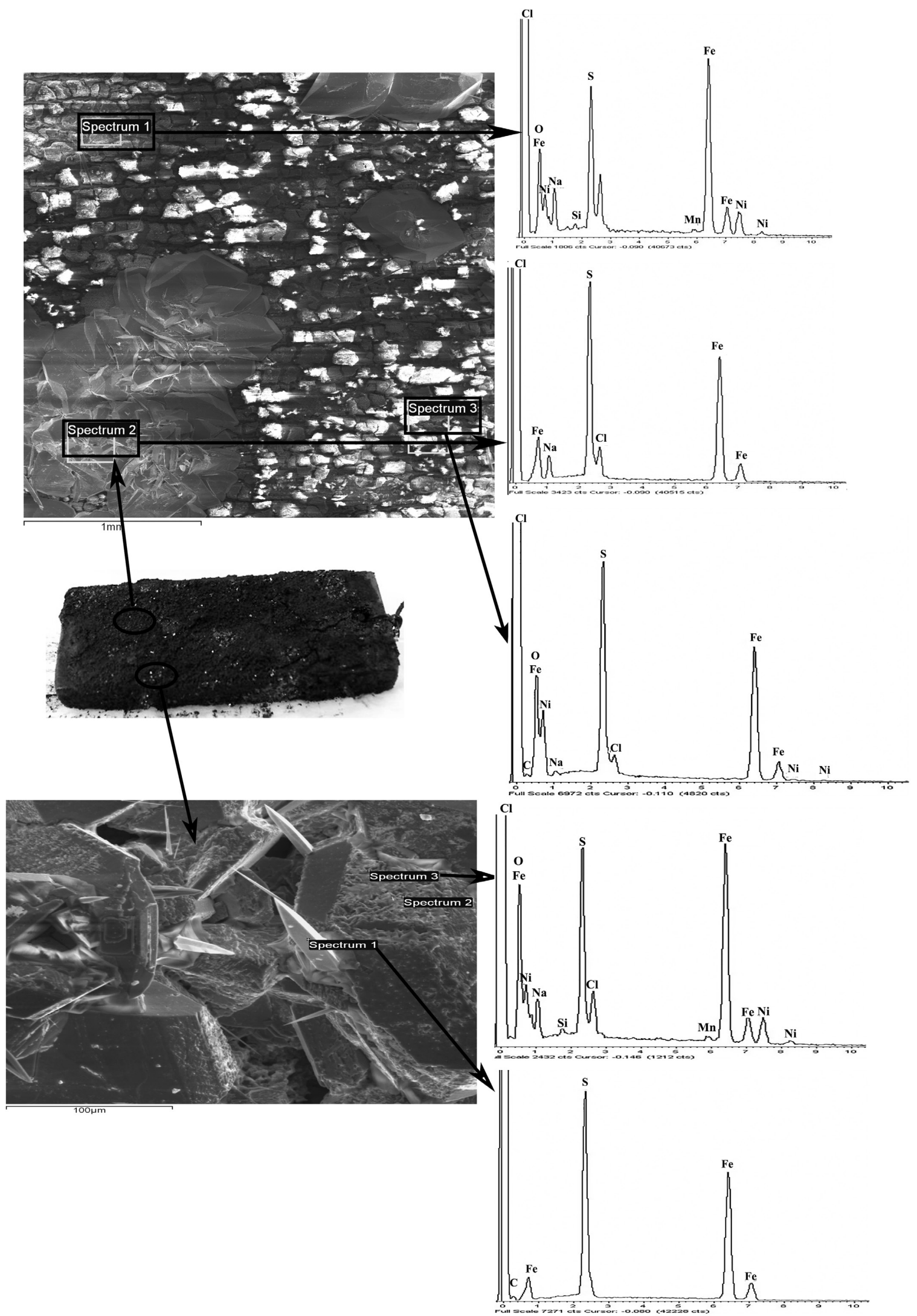

Figure 7. SEM and EDS characterization of the corrosion product film on the surface of the welded joint tested in solution 2, $\mathrm{pH}=3.0$. 


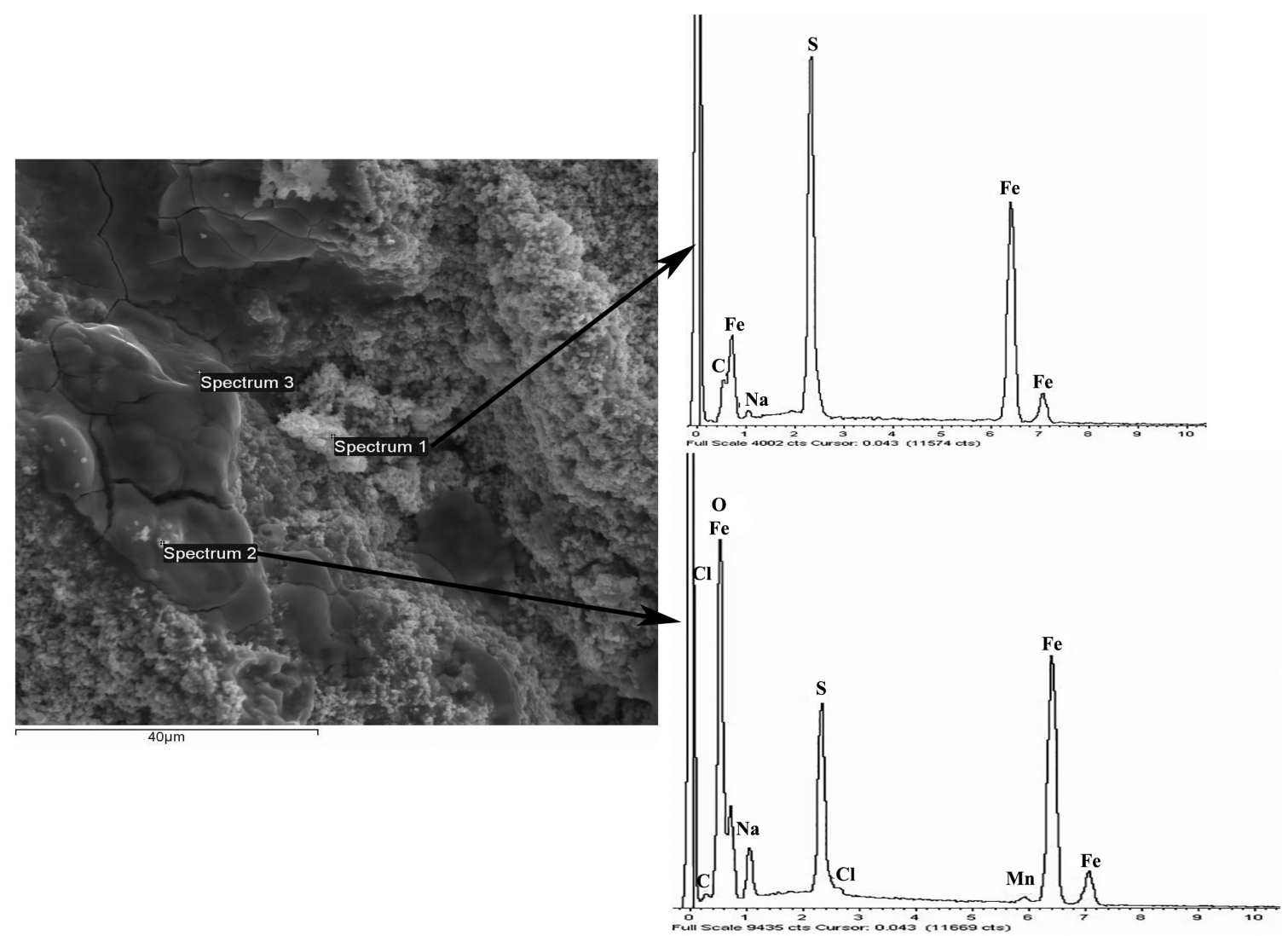

Figure 8. SEM and EDS characterization of the corrosion product film of the welded joint tested in solution 1, $\mathrm{pH}=3.0$.

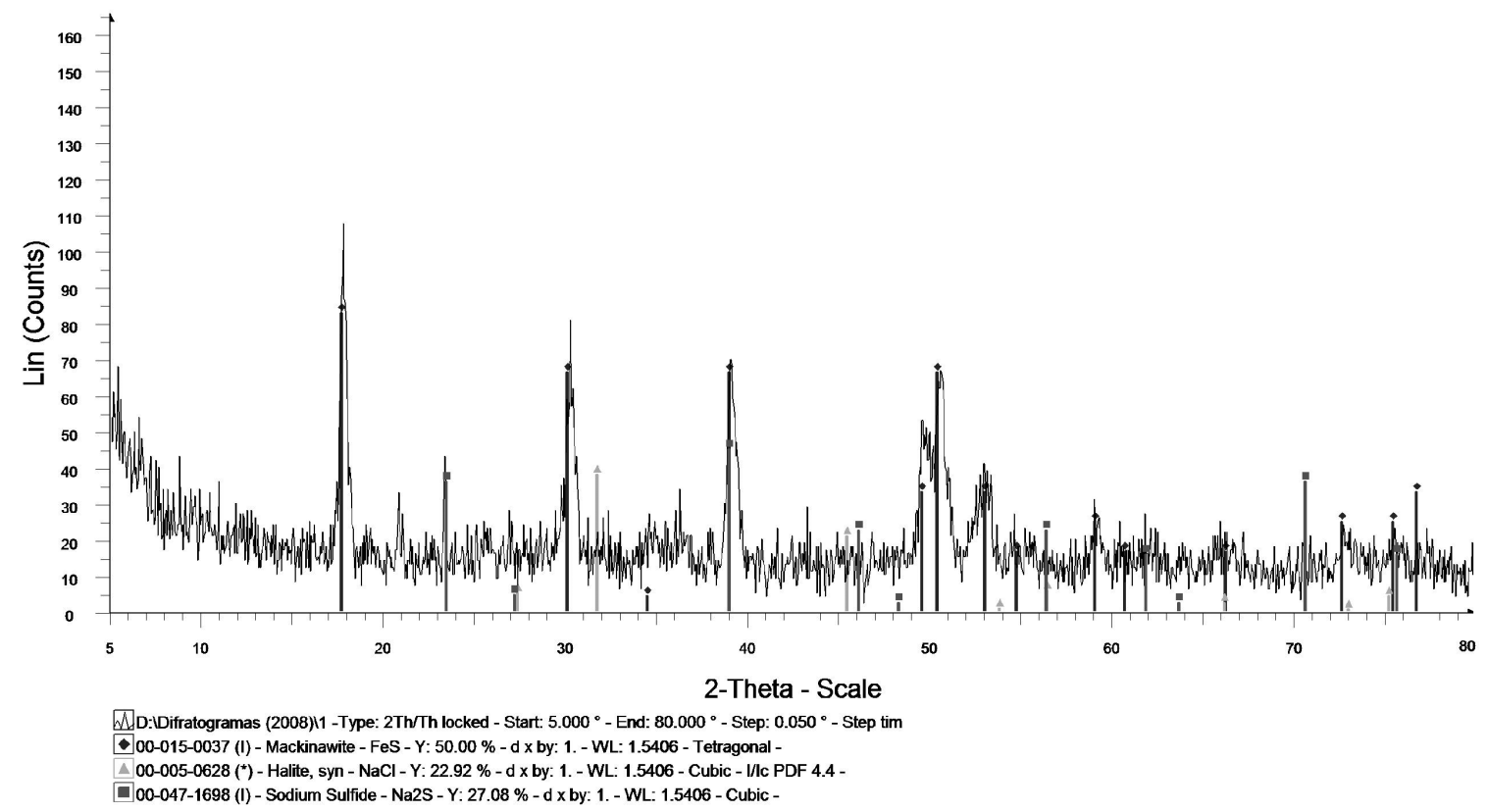

Figure 9. XRD spectrum of the corrosion product film of the welded joint tested in solution 2, $\mathrm{pH}=3.0$. 


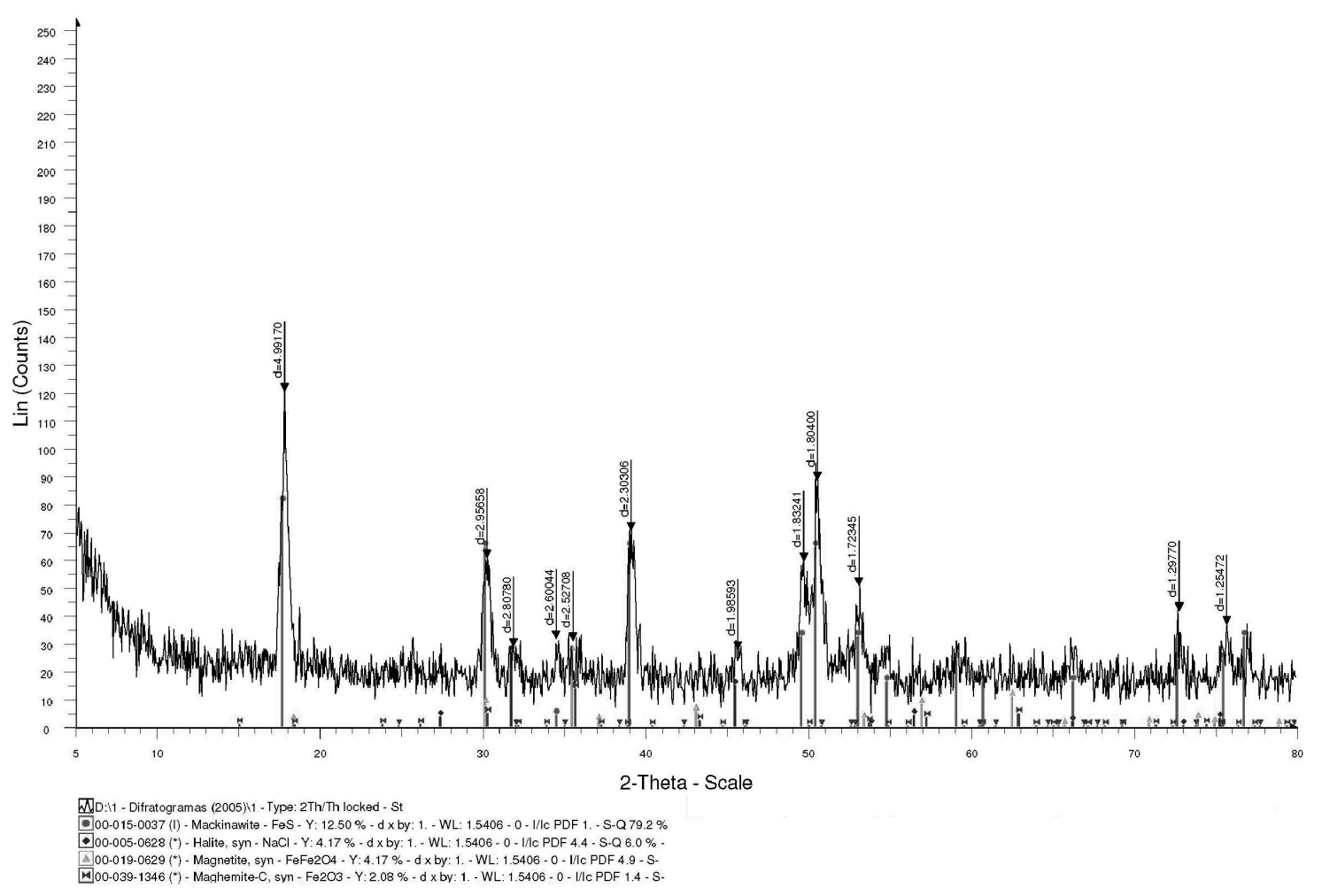

Figure 10. XRD spectrum of the corrosion product film of the welded joint tested in solution 1, $\mathrm{pH}=3.0$.

The corrosion film that formed for the $\mathrm{WJ}$ in solution 1 with $\mathrm{pH}=3.0$ (Figure 8) has different morphologies from that formed in solution 2 (Figure 7). The solution 1 film did not feature columnar crystal clusters. This film exhibits two different morphologies: an inner layer with a continuous and compact morphology adjacent to the metallic substrate surface and an outer layer with a discontinuous, porous and granular morphology above the inner layer. The EDS spectra (Figure 8) and XRD spectrum (Figure 10) show that the inner layer may be an iron oxide (magnetite or maghemite), and the outer layer may be an iron sulphide (mackinawite). The corrosion films that formed for solution 1 exhibit a more regular and compact morphology, which contributes to the formation of protective layers and thus decreases the corrosion rate.

Regarding the effect of the microstructure, the corrosion rates are lower for the fully BM samples, which have a ferritic microstructure and martensite-austenite microconstituent (MA). The metallographic analysis shows that at the HAZ (coarse-grain HAZ (CGHAZ) and fine-grain HAZ (FGHAZ)), the microstructure consists primarily of a bainitic ferritic matrix with decomposed MA, which suffered from severe localized attack (Figure 11). This result is consistent with the fact that the highest calculated corrosion rates were obtained for the WJ. Similar results were obtained by Forero et al. ${ }^{15}$ and Garcia et al. ${ }^{28}$, who studied the $\mathrm{H}_{2} \mathrm{~S}$ corrosion resistance of microalloyed steel with different microstructures. They observed lower corrosion rates for ferrite+MA microconstituents and an acicular ferritic

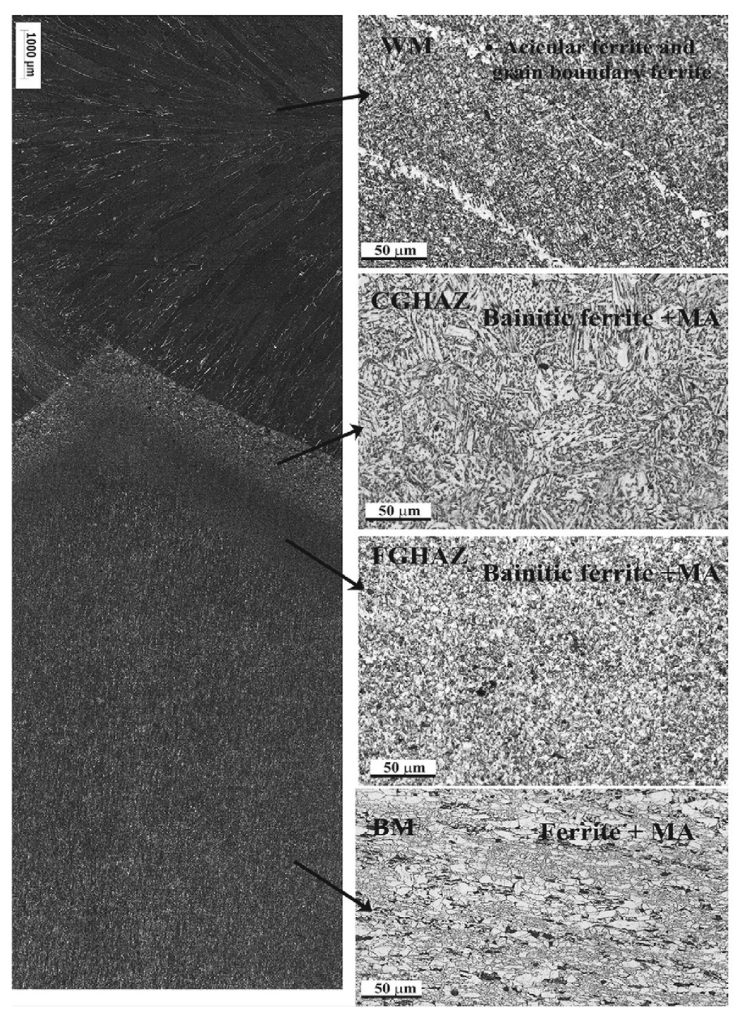

Figure 11. Optical microscopy characterization of localized attacks suffered by different microstructures on the welded joint surfaces after the electrochemical tests. 
microstructure than for ferritic-bainitic microconstituents and martensitic microstructures.

\section{Conclusions}

The corrosion rate increases with decreasing $\mathrm{pH}$ and increasing $\mathrm{H}_{2} \mathrm{~S}$ concentration generated by the thiosulphate. Solution 2, which has the highest thiosulphate concentration $\left(10^{-2} \mathrm{~mol} / \mathrm{l}\right)$, shows the highest corrosion rate, but this rate is lower for the low-concentration solution $\left(10^{-3} \mathrm{~mol} / \mathrm{L} \mathrm{Na}_{2} \mathrm{~S}_{2} \mathrm{O}_{3}\right)$. This effect is explained by the formation of a partially protective film on the samples in the solutions with low $\mathrm{H}_{2} \mathrm{~S}$ concentration.

\section{References}

1. Ma H, Cheng X, Li G, Chen S, Quan Z, Zhao S, et al. The influence of hydrogen sulphide on corrosion of iron under different conditions. Corrosion Science. 2000; 42(10):16691683. http://dx.doi.org/10.1016/S0010-938X(00)00003-2.

2. Tang J, Shao Y, Guo J, Zhang T, Meng G and Wang F. The effect of H2S concentrations behavior of carbon steel at 90 oC. Corrosion Science. 2010; 52(6):2050-2058. http://dx.doi. org/10.1016/j.corsci.2010.02.004.

3. Shoesmith DW, Taylor P, Bailey MG and Owen DG. Journal of the Electrochemical Society. 1980; 127(5):1007. http://dx.doi. org/10.1149/1.2129808.

4. Lee K-LJ and Nesic S. EIS investigation of CO2/H2S corrosion. Ohio: ICMT; 2004. Corrosion Paper 04728.

5. Cheng XL, Ma HY, Zhang JP, Chen X, Chen SH and Yang HQ. Corrosion of iron in acid solutions with hydrogen sulfide. Corrosion. 1998; 54(5):369-376.

6. Choi YS, Nesic S and Ling S. Effect of H2S on the CO2 corrosion of carbon steel in acidic solutions. Electrochimica Acta. 2011; 56:1752-1760.

7. Kermani B, Martin J and Esaklul K. Materials design strategy: effects of $\mathrm{H} 2 \mathrm{~S} / \mathrm{CO} 2$ corrosion on materials selection. Houston: NACE; 2006. Corrosion Paper 06121.

8. Arzola S, Mendoza J, Duran R and Genesca J. Electrochemical Behavior of API X70 Steel in Hydrogen Sulfide-Containing Solutions. Corrosion. 2006; 62(5):433-442. http://dx.doi. org/10.5006/1.3278280.

9. Zhou C, Zheng S, Chen $\mathrm{C}$ and Lu G. The effect of the partial pressure of $\mathrm{H} 2 \mathrm{~S}$ on the permeation of hydrogen in the low carbon pipelines steel. Corrosion Science. 2013; 67:184-192. http://dx.doi.org/10.1016/j.corsci.2012.10.016.

10. Ren C, Liu D, Bai Z and Li T. Corrosion behaviour of oil tube steel in simulant solution with hydrogen sulfide and carbon dioxide. Materials Chemistry and Physics. 2005; 93(2-3):305309. http://dx.doi.org/10.1016/j.matchemphys.2005.03.010.

11. Park GT, Koh SU, Jung HG and Kim KY. Effect of microstructure on the hydrogen trapping efficiency and hydrogen induced cracking of line pipe steel. Corrosion Science. 2008; 50(7):18651871. http://dx.doi.org/10.1016/j.corsci.2008.03.007.

12. Koh SU, Kim JS, Yang BY and Kim KY. Effect of line pipe steel microstructure on susceptibility to sulfide stress cracking. Corrosion. 2004; 60(3):244-253. http://dx.doi. org/10.5006/1.3287728.

13. Carneiro RA, Ratnapuli RC and de Freitas Cunha Lins V. The influence of chemical composition and microstructure of API linepipe steels on hydrogen induced cracking and sulfide stress corrosion cracking. Materials Science and Engineering
The corrosion product films that were formed on the two surfaces (BM and WJ) under all test conditions consist of two layers of different morphologies, which depend on the $\mathrm{H}_{2} \mathrm{~S}$ concentration.

The heat-affected zone (HAZ) showed severe localized corrosion attack, which was attributed to the microstructural characteristics of this region.

\section{Acknowledgements}

The authors wish to acknowledge the financial support of CAPES, CNPq, and Faperj.

A. 2003; 357(1-2):104-110. http://dx.doi.org/10.1016/S09215093(03)00217-X.

14. Zhao MC and Yang K. Strengthening and improvement of sulfide stress cracking resistance in acicular ferrite pipeline steels by nano-sized carbonitrides. Scripta Materialia. 2005; 52(9):881886. http://dx.doi.org/10.1016/j.scriptamat.2005.01.009.

15. Forero AB and José AC. Ponciano Gomes, Bott. I.S, Susceptibility of pipeline girth welds to hydrogen embrittlement and sulphide stress cracking. Materials and Corrosion. 2014; 65(5):531-541.

16. Bott IS, Souza LFG, Teixeira JCG and Rios PR. High strength HTP steel development for pipelines: A Brazilian perspective. Metal Mat Trans. A. Physical Metallurgy and Materials Science. 2005; 36A:443-454. http://dx.doi.org/10.1007/s11661-0050315-9.

17. Lu BT and Luo JL. Relationship between yield strength and near neutral $\mathrm{pH}$ stress corrosion cracking resistance of pipeline steels- An effect of microstructure. Corrosion Science. 2006; 62(2):129-140. http://dx.doi.org/10.5006/1.3278258.

18. Albarran JL, Martinez L and Lopez HF. Effect of heat treatment on the stress corrosion resistance of the microalloyed pipelines steel. Corrosion Science. 1999; 41(6):1037-1049. http://dx.doi. org/10.1016/S0010-938X(98)00139-5.

19. Bulger J and Lou J. Effect of microstructure on near-neutral pH SCC. In: International Pipeline Conference. New York: ASME; 2000. v. 2.

20. Leyer J, Sutter P, Marchebis H, Bosch C, Kulgemeyer A and Orlans B. SSC resistance of a $125 \mathrm{Ksi}$ steel grade in slightly sour environments. NACE International; 2005. Corrosion Paper 05088.

21. Natividad C, Salazar M, Garcia R, Gonzalez-Rodriguez JG and Perez R. Sulfide stress cracking behavior of weldments produced by indirect electric arc welding. Corros. Eng. Sci. Technol. 2006; 41(1):91-95. http://dx.doi.org/10.1179/174327806X93974.

22. Natividad C, Salazar M, Contreras A, Albiter A, Pérez R and Gonzalez-Rodriguez JG. Sulfide stress cracking susceptibility of X-60 and X-65 steel weldments. Corrosion. 2006; 62(5):375382. http://dx.doi.org/10.5006/1.3278275.

23 Beavers JA, Jonson JT and Sutherby RL. Materials factors influencing the initiation of near-neutral pH SCC on underground pipelines. In: Proceedings of the International Pipeline Conference. New York: ASME International; 2000. p. 979-988. V. 2.

24. Omweg GM, Frankel GS, Bruce WA, Ramirez JE and Koch G. Effect of welding parameters and $\mathrm{H} 2 \mathrm{~S}$ partial pressure on the susceptibility of welded HSLA steel to sulfide stress cracking. Welding Research. 2003: 136-143.

25. American Society for Testing and Materials - ASTM. ASTM E 415. West Conshohocken; 2008. 
26. American Society for Testing and Materials - ASTM. ASTM G1-03. West Conshohocken; 2011.

27. Kane RD. Roles of $\mathrm{H} 2 \mathrm{~S}$ in behaviour of engineering alloys. International Metals Reviews. 1985; 30(6):291-301.

28. Lucio-Garcia MA, Gonzalez-Rodriguez JG, Casales M, Martinez L, Chacon-Nava JG, Neri-Flores MA, et al. Effect of heart treatment on H2S corrosion of micro-alloyed C-Mn Steel. Corrosion Science. 2009; 51(10):2380-2386. http://dx.doi. org/10.1016/j.corsci.2009.06.022.

29. Zucchi F, Trabanelli G, Monticelli C and Grassi V. SCC inhibition of a $\mathrm{C}$-steel in acidic $5 \% \mathrm{NaCl}$ solutions in the presence of thiosulphate. Corrosion Science. 2000; 42(3):505-515. http:// dx.doi.org/10.1016/S0010-938X(99)00104-3.

30. Fragiel B, Serna S and Perez R. Electrochemical study of two microalloyed pipeline steels in $\mathrm{H} 2 \mathrm{~S}$ environments. International
Journal of Hydrogen Energy. 2005; 30(12):1303-1309. http:// dx.doi.org/10.1016/j.ijhydene.2005.04.006.

31. Maddala J, Sambath K, Kumar V and Ramanahan S. Identification of reaction mechanism for anodic dissolution of metals using Electrochemical Impedance Spectroscopy. Journal of Electroanalytical Chemistry. 2010; 638(2):183-188. http:// dx.doi.org/10.1016/j.jelechem.2009.11.021.

32. Abd-El-Khaled DE and Abd-El-Nabey BA. Evaluation of sodium hexametaphosphate as scale and corrosion inhibitor in cooling water using electrochemical techniques. Desalination. 2013; 311:227-233. http://dx.doi.org/10.1016/j.desal.2012.11.017.

33. Huang H, Tsai W and Lee J. Corrosion Morphology of A516 Carbon-Steel in H2S Solution. Scripta Metallurgica et Materialia. 1994; 31(7):825-828. http://dx.doi.org/10.1016/0956716X(94)90486-3. 